\title{
HEGEMONIC MASCULINITY \\ Wacana Relasi Gender dalam Tinjauan Psikologi Sosial
}

\author{
Oktarizal Drianus \\ IAIN Syaikh Abdurrahman Siddik Bangka Belitung, Indonesia \\ oktarizaldrianus@iainsasbabel.ac.id \\ Rusdian Dinata \\ IAIN Syaikh Abdurrahman Siddik Bangka Belitung, Indonesia \\ rusdiandinata@gmail.com
}

\begin{abstract}
Today, world is languishing in a patriarchal structure. This patriarchal domination not only harms women, but also men, children, the elderly, and marginalized groups. Gender mainstreaming extends its studies not only to femininity, but to parenting (motherhood and fatherhood), early childhood. In addition, gender also extends to the realm of masculinity or male studies. In this case, gender psychology underlines this phenomenon with hegemonic masculinity discourse. Masculinity is seen from the dominance of the spaces of life both public and private. This paper examines the ideology of hegemonic masculinity as the most desirable theoretical response to Critical Men Studies (CSM). This elaboration of the Hegemonic Masculinity concept is useful as a 'binocular tool' that is operational for empirical studies of masculinity. In other words, the theorethical perspective has a benefit for field of critical psychology, and even psychology of gender.
\end{abstract}

Keywords; patriarchal structure, gender, hegemonic masculinity, Critical Men Studies (CSM), psychology of gender.

\begin{abstract}
Abstrak
Dunia hari ini sedang mendekam dalam struktur patriarki. Dominasi patriarki ini tidak hanya merugikan perempuan, melainkan juga laki-laki, anak-anak, lansia, dan kelompok-kelompok marjinal. Pengarusutamaan gender memperluas kajiannya tidak hanya pada femininitas, melainkan pada pengasuhan (motherhood dan fatherhood), anak usia dini. Selain itu, gender juga memperluas ke ranah maskulinitas atau studi laki-laki. Dalam hal ini, psikologi gender meneropong fenomena ini dengan wacana hegemonic masculinity. Maskulinitas dilihat dari dominasi terhadap ruang-ruang kehidupan baik publik maupun privat. Tulisan ini mengupas mengenai ideologi hegemonic masculinity sebagai lanksap teoretis yang paling diminati untuk Studi Kritis Laki-Laki (Critical Men Studies). Pembedahan konsep Hegemonic Masculinity ini berguna sebagai 'alat teropong' yang operasional bagi studi empiris terhadap maskulinitas. Dengan kata lain, perspektif teoretis ini mempunyai kontribusi terhadap bidang psikologi kritis maupun psikologi gender.
\end{abstract}

Kata kunci; struktur patriarkis, gender, maskulinitas hegemonik, Studi Kritis Laki-Laki, psikologi gender. 


\section{Pendahuluan}

Ada paradoks yang mendekam apabila dilihat dengan lensa genderdimana dunia yang dihuni (life world) merupakan suatu tatanan kehidupan yang berstruktur patriarki (Asadi, 2010; Hasyim et al., 2011; Akman, 2013; Meyer \& Barnard, 2015). Alih-alih adil secara gender, patriarki justru mengakibatkan ketimpangan relasi gender antara lakilaki dan perempuan yang dapat termnifestasi dalam berbagai bentuk pada praktik sosial masyarakat.

Pencandraan kritis ini sejalan dengan Kimmel (2000) yang menegaskan bahwa potret perbedaan gender (gender differences) hari ini telah melahirkan ketidakadilan gender (gender inequality). Pada sisi praktik, struktur patriarki yang memproduksi ketidakadilan gender seperti yang ditengarai Walby (2014), telah meresap ke dalam pelbagai lapisan baik makro maupun mikro, sadar atau tidak sadar, privat maupun publik. Bentuk-bentuk konkritnyanya dapat diselidiki pada pembagian kerja dan upah, produksi rumah tangga, budaya, seksualitas, hingga kebijakan negara.

Pendeknya, sebagian besar aspek kehidupan -jika tidak menyebut seluruhnya- turut mengamini dan melanggengkan struktur patriarki ini. Akibatnya, dunia kehidupan yang dijanjikan secara elok dan indah bagi lansia seperti yang diudar di awal menjadi ambivalen.

Tatanan sosial yang bias gender ini lantas memproduksi kekerasan dalam berbagai level dan bentuk baik struktural maupun kultural. Beberapa implikasi yang terjadi diantaranya: domestifikasi perempuan berbentuk kekerasan rumah tangga (domestic violence ataupun intimate partner violence) (Hasyim et al., 2011; Fulu et al, 2013), pemerkosaan (UNDP, 2016), tawuran antar remaja dan gangster, penyalahgunaan alkohol dan obatobatan terlarang (Barker, 2005; Nilan, 2009), pornografi (Flood, 2010; 2016), kesehatan dan well-being (Courtenay, 2000; Lohan, 2007; Smith, 2007; Evans et al., 2011; Robertson, dkk. 2016; Wong et al., 2016), kekerasan simbolik dan ketimpangan di ranah pendidikan (Lesko, 2000; Lingard et al., 2009; Davis, 2015), dan banyak lagi ketimpangan dan produksi patologi sosial berbasis gender lainnya (Greig et al. 2000).

Buchbinder (2013) menandaskan bahwa struktur patriarki ini tidak hanya mengorbankan perempuan saja, akan tetapi laki-laki juga. Ketimpangan struktur ini tidak hanya dilihat dari oposisi biner, laki-laki menindas dan perempuan korban penindasan. Justru, struktur yang seperti ini merugikan perempuan sekaligus laki-laki. Akan tetapi, tidak semua laki-laki yang dirugikan atau diuntungkan, melainkan hanya segelintir saja.

Connell \& Messerschmidt (2005) menyebut hanya segelintir laki-laki yang menentukan standar normatif bagaimana mestinya menjadi laki-laki. Seturut dalil di atas, dapat dipahami bahwa tidak hanya perempuan yang menjadi korban, namun laki-laki yang menjadi kiblat normatif dapat mendominasi laki-laki yang secara deskriptif berada pada tepian, pada batas pengecualian. 
Bersesuaian dengan konteks di atas, dominasi ini tampak pada misalnya konsep laki-laki dewasa yang kuat, sukses, kaya (pusat hegemoni) terhadap laki-laki yang secara material justru mengalami penurunan dan tidak identik dengan ciri dominan (subordinat dan marjinal).

Maskulinitas bukanlah bentuk tunggal, akan tetapi plural yang memiliki wajah beragam dalam representasi kulturalnya, Aboim (2010) menyebut realitas majemuk ini sebagai plural masculinities. Maskulinitas jamak ini terserak di pelbagai kultur, etnis, ras, agama, kelas sosial, maupun usia yang bersesuaian dengan penguasaan relasi produksi dan relasi kekuasaan.

Tulisan ini memiliki tendensi mengurai seperti apa wacana maskulinitas yang beroperasi pada kultur masyarakat hari ini. Selain itu, penulis bermaksud menunjukkan bagaimana menentukan struktur relasi yang hegemonik. Pada titik ini, gender dilihat sebagai suatu praktik sosial (social practice).

\section{Multiplisitas Definisi Maskulinitas}

Term maskulinitas (masculinity) merupakan ikon kunci pada berbagai studi mengenai laki-laki dan gender seperti yang telah diuraikan di atas. Oleh sebab itu, membahas maskulinitas tidak boleh lepas dari perspektif gender, karena maskulinitas terkait dengan konstruksi sosial. Maskulinitas (masculinity) merupakan kata yang 'licin' dalam rentang kajian akademis mengenai laki-laki dan gender.

Flood, dkk. (2007) mencatat bahwa konsep maskulinitas muncul pada akhir tahun 1970-an. Kata maskulin diderivasi dari kata masculin (Inggris abad Pertengahan), masculinus (Perancis abad Pertengahan) yang artinya laki-laki (male, male person, of masculine gender), masculus (Latin) yang artinya laki-laki. Pada awalnya kata maskulin mengacu pada kualitas yang dimiliki oleh jenis kelamin laki-laki, seperti kekuasaan, kelelakian, dan kejantanan.

Connell (2001) menegaskan bahwa maskulinitas bukanlah oposisi biner dari femininitas. Maskulinitas bukanlah suatu objek yang terisolasi, melainkan aspek dari struktur yang lebih besar, misalnya hierarki sosial. Dengan kata lain, usaha pendefinisian maskulinitas kontemporer bukan dari ketiadaan femininitas (melalui negasi naif atas feminine), atau "apa yang bukan feminin". Sebaliknya, maskulinitas lebih kompleks dari negasi biner tersebut.

Flood (2002) melakukan pengujian atas beragamnya usaha pendefinisian term maskulinitas yang dilakukan oleh sejumlah akademisi. Ikhtiar ini dapat membantu untuk melihat peta konseptual sepanjang perumusan istilah ini. Lebih lanjut, Flood (2002) melihat ada tiga gugus fenomena relevan yang kerap diacu sebagai maskulinitas, antara lain:

1. Maskulinitas mengacu kepada kepercayaan, ideal, imagi, representasi, dan wacana.

2. Maskulinitas mengacu kepada sifatsifat yang membedakan laki-laki dan perempuan.

3. Maskulinitas mengacu kepada strategi laki-laki yang berkuasa atau strategi untuk melanggengkan kekuasaan laki-laki. 


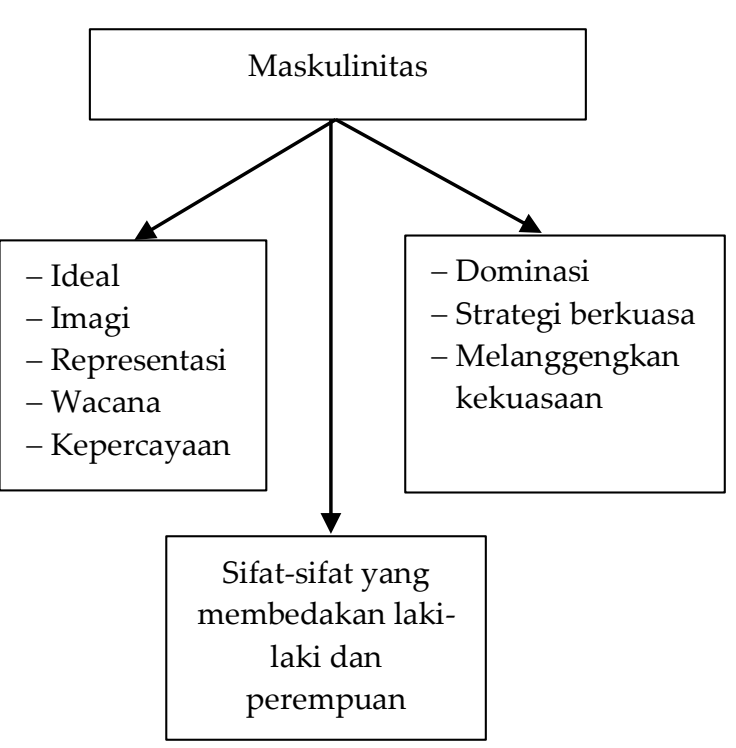

Gambar 1. Tiga gugus pemaknaan maskulinitas (Flood, 2002).

Pemetaan di atas memberikan gambaran bahwa maskulinitas merupakan ranah multiplisitas sehingga tidak dapat direduksi menjadi definisi yang tunggal (Howson, 2006; Aboim, 2010). Selain itu, maskulinitas bukanlah hal tetap (fix) yang tidak berubah dan statis. Pemetaan di atas mengisyaratkan bahwa maskulinitas merupakan suatu cara mengada (way of being) laki-laki pada suatu masyarakat tertentu.

Hal ini sejalan dengan argumen Kimmel \& Messner (2007) yang mengatakan bahwa laki-laki tidak dilahirkan, melainkan diciptakan oleh mereka sendiri yang secara aktif mengkonstruksi maskulinitasnya dalam konteks sosial dan sejarah. Artinya, menjadi laki-laki merupakan konstruksi sosial yang dibangun, diciptakan, diterima, dinormalkan, kemudian dilanggengkan konstruksi tersebut dalam ruang dan waktu. Hal inilah yang menjadikan term maskulinitas menjadi jamak dan tergantung dengan konteks lokal dan sosial pada suatu masyarakat.

\section{Pluralitas makna ini}

memungkinkan maskulinitas dilihat sebagai suatu konfigurasi tindakan pada suatu sistem relasi gender (Connell, 2001). Oleh karenanya, perwujudan maskulinitas sebagai konstruksi sosial pada suatu masyarakat sangat beragam, tergantung konteks relasi gender yang berlaku.

Perkembangan pendefinisian maskulinitas yang dicatat oleh Connell (2005) berusaha mengkaji secara kritis terhadap berbagai pendekatan atas topik ini, diantaranya:

1. Pendekatan esensial yang menitikberatkan definisi pada inti maskulin dan berkutat pada kehidupan laki-laki. Maskulinitas setara dengan aktivitas yang merupakan sisi kontras dari pasivitas feminin;

2. Pendekatan positivistik yang menekankan pada fakta bahwa maskulinitas merupakan apa yang aktual pada laki-laki, misalnya menyangkut sikap, sifat, dan kategori-kategori ajeg mengenai maskulinitas;

3. Pendekatan normatif yang menekankan pada standar bagaimana laki-laki seharusnya menjadi. Misalnya melalui media dan norma sosial yang berlaku;

4. Pendekatan semiotik yang mendefinisikan maskulinitas melalui perbedaan simbolis dimana maskulin dan feminin ditempatkan secara kontras.

Titik kritik Connell (2005) terhadap beberapa pendekatan di atas adalah adanya kecenderungan mendefinisikan maskulinitas sebagai suatu objek, baik sebagai tipe karakter 
alami, rata-rata perilaku, suatu norma tetap, maupun sebagai penanda simbolik (misalnya penis sebagai simbol laki-laki).

Menurut Connell (2005), perlu ditambahkan titik fokus pada proses dan relasi bagaimana laki-laki dan perempuan menjalani kehidupan gendernya. Maskulinitas diperluas cakupannya dengan sekaligus mempertimbangkan posisi dalam hubungan gender, praksis bagaimana laki-laki dan perempuan terlibat, serta efek dari praktik gender tersebut terhadap pengalaman ketubuhan, personalitas, dan budaya.

Catatan kritis di atas menempatkan maskulinitas dalam tatanan konfigurasi bagaimana laki-laki menjalani kehidupannya pada suatu struktur masyarakat yang melibatkan pengalaman subjektifnya, relasi dengan perempuan maupun kelompok lainnya, serta bagaimana pola relasi kekuasaan, relasi produksi, dan relasi lainnya saling berdialektika dan saling membentuk dengan struktur sosialnya.

\section{Kerangka Konseptual Hegemonic Masculinty}

Uraian di atas menerangkan bahwa maskulinitas mempunyai wujud yang jamak terkait relasinya dengan gender, ras, kelas, serta usia, misalnya kulit hitam maupun kulit putih, kelas bahwa dan kelas menengah, bahkan remaja ataupun orang tua. Maskulinitas pada praktik sosial tidak seragam dan dinamis, baik imagi, representasi, kepercayaan, budaya, agama, gaya hidup, tujuan-tujuan hidupnya, maknamakna pengalaman sehari-harinya. Hal ini berdampak bagaimana penentuan relasi kekuasaan, relasi produksi, maupun relasi interpersonal pada tataran mikro (misalnya keluarga, sekolah, tempat kerja, komunitas tertentu) dan tataran makro (bangsa, negara, wilayah).

Ranah kehidupan di atas bukanlah ranah yang kaku dan tidak saling terkait, melainkan saling tembus, lentur, dan berkelindan. Kompleksitas gender ini dapat dijelaskan dengan konsep maskulinitas hegemonik. Konsep ini (hegemonic masculinity) merupakan teori mengenai maskulinitas yang sangat luas digunakan hari ini.

Connell (2005) mendefinisikan hegemonic masculinity sebagai "the configuration of gender practice which embodies the currently accepted answer to the problem of legitimacy of patriarchy, which guarantees (or is taken to guarantee) the dominant position of men and the subordination of women". Konsep ini dipahami sebagai suatu konfigurasi sistem relasi gender.

Connell (2005) mengajukan model maskulinitas hegemonik untuk melakukan kritik terhadap male sex role yang cenderung simplistik dan kejamakan dalam melihat maskulinitas serta relasi kekuasaan. Mengingat lentur dan kompleknya posisi gender ini, maka perlu suatu konsep yang melampaui (beyond) konsepsi peran serta menguak relasi gender yang terjadi pada tataran praktik kehidupan sehari-hari. Maskulinitas hegemonik menyajikan pisau analisis yang dapat menguak pengalaman subjektif sekaligus analisis posisi kekuasaan dalam masyarakat patriarki. 
Connell (2005) menyebutkan bahwa maskulinitas hegemonik bukanlah suatu karakter yang tetap, selalu dan dimana saja sama. Lebih lanjut, term ini ingin menunjukkan bahwa ada maskulinitas yang menempati posisi hegemonik pada suatu pola tertentu dari relasi gender. Posisi ini dapat dipertentangkan dan diperebutkan.

Maskulinitas

hegemonik merupakan suatu pola praktik -tidak hanya identitas maupuan peran yang diharapkan- yang memungkinkan dominasi laki-laki terhadap perempuan terus berlanjut (Connell, 2005), bahkan dominasi terhadap sesama laki-laki. Hegemoni ini terkait dengan struktur yang melingkupinya.

Ada beberapa pola yang terkait dengan maskulinitas hegemonik. Connell (2005) mengajukan beberapa pola utama yang beroperasi dalam menjelaskan maskulinitas dan gender, diantaranya:

1. Maskulinitas Hegemonik (hegemonic masculinity).

Term hegemoni yang diderivasi dari teori sosial ini merupakan alat analisis relasi kelas yang mengacu pada dinamika kultural pada kondisi suatu kelompok mengklaim dan melanggenggkan posisi pada kehidupan sosial. Pada waktu tertentu, satu bentuk maskulinitas diistimewakan secara kultural dibandingkan kelompok lainnya. Kelompok kecil yang mendapat keistimewaan ini yang disebut dengan maskulinitas hegemonik.

Connell (2005) mendefinisikan maskulinitas hegemonik sebagai konfigurasi praktik gender yang menjelma dalam bentuk pengakuan yang diterima terhadap masalah legitimasi patriarki, yang menjamin (dianggap wajar) posisi dominan laki-laki dan subordinasi perempuan. Singkatnya, dominasi tidak selalu beroperasi melalui kekerasan (koersif), melainkan melalui persuasi, budaya, dan institusi.

Wujud konkret maskulinitas hegemoni pada kehidupan seharihari misalnya seorang aktor yang populer, pemain sepakbola terkenal, atau bisa saja seseorang yang mempunyai pangkat tinggi atau kehidupan yang mapan, bahkan seorang yang menjadi acuan dalam suatu masyarakat. Singkatnya, maskulinitas hegemonik menentukan bagaimana harusnya menjadi laki-laki.

2. Maskulinitas Subordinat (subordinated masculinity).

Maskulinitas subordinat merupakan bentuk maskulinitas yang menjadi sasaran hegemoni, misalnya kaum gay terhadap lakilaki heteroseksual dalam suatu kultur masyarakat tertentu. Posisi subordinasi ini seringkali memungkinkan kekerasan yang dilakukan secara sah terhadapnya, diskriminasi ekonomi, posisi ditindas.

Penindasan tidak selalu dalam bentuk kekerasan fisik, akan tetapi bisa saja dalam bentuk kekerasan simbolik melalui legitimasi budaya, kepercayaan tertentu, maupun peran tertentu. Misalnya, perempuan bekerja di ranah domestik (tidak dibayar) dan laki- 
laki bekerja di ranah publik (memiliki gaji).

Posisi ini memungkinkan adanya subordinasi terhadap perempuan dikarenakan laki-laki mempunyai kapital ekonomi. Kekerasan rumah tangga dan pelecehan seksual kerap terjadi pada posisi subordinasi ini. Connel (2005) mengatakan bahwa subordinasi dapat juga dalam bentuk pelecahan (abuse) melalui bahasa, misalnya pada laki-laki yang dianggap berbeda dengan sederet kosakata yang mengandung pelecehan.

3. Maskulinitas Komplisit (complicit masculinity).

Connell (2005) menerangkan bahwa sedikit sekali laki-laki yang memenuhi standar normatif yang berlaku pada maskulinitas hegemonik. Jumlah laki-laki yang mempraktikkan secara ketat pola hegemonik mungkin sangat kecil. Akan tetapi, sebagian laki-laki memperoleh keuntungan dari pola hegemoni karena adanya pembedaan patriarkis dan keuntungan dari subordinasi perempuan.

Maskulinitas komplisit tidak secara frontal melakukan dominasi terhadap perempuan maupun lakilaki lainnya, melainkan secara tidak langsung turut terlibat dalam proyek maskulinitas hegemonik. Akan tetapi, maskulinitas komplisit turut melanggengkan dan menerima keuntungan dari posisi dominasi dalam tatanan patriarki. Misalnya, pusat kebugaran atau kecantikan yang memanfaatkan citra dominan untuk meraih keuntungan.
4. Maskulinitas Marjinal (marginalized masculinity).

Maskulinitas termrjinalkan (marginalized masculinity) bukanlah relasi pada kelas dominan dan subordinat. Marjinalisasi merupakan peminggiran oleh otoritas hegemonik kelompok dominan. Connell (2005) menyebutkan bahwa relasi antara marginalisasi dan otorisasi juga terjadi pada kelompok subordinat.

Connell (2005) menyebut contoh maskulinitas marjinal ini adalah atlet kulit hitam di Amerika. Prestasinya terlihat jelas pada kancah olahraga di Amerika. Akan tetapi, hal ini tidak dapat melahirkan otoritas sosial kaum kulit hitam secara umum.

\section{Stereotype Maskulinitas melalui Media}

Salah satu tipe maskulinitas yang disebut oleh Nilan (2009) adalah maskulinitas yang diproduksi oleh representasi sosial yaitu hypermasculinity. Term ini identik dengan sosok yang kuat, keras, dan heroik. Hypermasculinity merupakan citra rekaan media yang berkepentingan terhadap visi industri kapitalis, misalnya hendak meraih keuntungan finansial sebanyak-banyaknya dari produk yang ditawarkan. Hypermasculinity diapropriasi sebagai imagi yang normal dan standar, meskipun dalam kehidupan riil sosok tersebut tidak pernah dijumpai, misalnya sosok superman dalam film.

Contoh sosok hipermaskulin yang berkaitan dengan lansia laki-laki pada tayangan film dan televisi 
dialamatkan oleh Feasey (2008; 2011) yang menentang ketidakmasukalan citra populer pada laki-laki, dimana citra hipermaskulin ini bersembunyi dibalik penonjolan kedok kekuatan fisik yang heroik daripada kematangan moral dan kebijaksanaan. Konsekuensi logisnya, lak-laki lansia atau seusianya yang tidak identik seperti pada film tersebut bukanlah sebagai laki-laki.

Dukungan media yang cenderung melanggengkan sosok hipermaskulin ini tampak pula pada representasi maskulin pada majalahmajalah remaja. Ismail (2014) dengan tajam menunjukkan bahwa citra maskulin dominan beroperasi melalui hubungan heteroseksual romantis, dimana laki-laki dan perempuan turut berperan dalam membentuk maskulinitas dominan.

Aspek sosio-kultural masyarakat termsuk pemahaman agama yang rigid juga turut ambil bagian dalam rangka memproduksi imagi maskulinitas yang diharapkan, begitu juga imagi tentang perempuan (Hayati et al., 2014; Permanadeli, 2015). Konstruksi sosiokultural ini dengan sendirinya terinternalisasi pada diri subjek sekaligus membentuk struktur sosial. Sehingga seolah-olah ada kesepakatan bersama antara subjek dalam suatu konteks masyarakat untuk menentukan imagi maskulinitas tunggal yang mengungguli serta menegasi jenis maskulinitas lainnya.

Connell (2005) memformulasikan maskulinitas dominan ini sebagai hegemonic masculinity. Term ini digaungkan untuk menunjukkan dominasi dari sejumlah laki-laki yang secara statistik bukanlah mayoritas.
Akan tetapi, memposisikan diri pada posisi istimewa sehingga dianggap sebagai patokan normatif (Connell, 2005).

Connell (2005) menunjukkan bahwa hegemonic masculinity ini berwajah plural dan bukanlah melekat (fix) pada suatu kelompok tertentu. Dengan kata lain, maskulinitas hegemonik terkait dengan posisi kekuasaan dalam struktur. Ia merupakan suatu pola praktik -seperti harapan akan peran tertentu atau indentitas- yang memungkinkan dominasi laki-laki terhadap perempuan atau jenis laki-laki dan posisi lainnya.

Hegemoni yang dimaksudkan tidak melulu melalui kekerasan (koersif) meskipun disokong dengan kekuatan, namun pengaruh kekuasaannya beroperasi secara halus melalui budaya, institusi, dan persuasi. Maskulinitas hegemonik beroperasi melalui pengakuan dan persetujuan dari pihak yang didominasi.

Kerangka yang disajikan Connell (2005) di atas memungkinkan untuk melihat interseksi dan jalinan yang berkelindan antara maskulinitas, struktur dan praktik sosial yang terbentuk di masyarakat dimana ketidakadilan gender yang melibatkan jenis kelamin, ras, kepercayaan, kelas sosial, dan usia terus-menerus diproduksi. Struktur maskulinitas yang hegemonik ini mengunggulkan satu tipe maskulinitas sekaligus mendominasi dan merugikan femininitas dan maskulinitas lainnya.

Maskulinitas hegemonik yang disebut di atas menjadi berguna untuk melihat posisi kelompok-kelompok marjinal, misalnya laki-laki lansia, para 
pekerja digital, gay, difabel, kutu buku, dan laki-laki yang tidak mengacu kepada standar normatif dimana ia tinggal. Pada tataran realitas, praktik kehidupan sehari-hari telah mewedarkan adanya pandangan umum yang berlaku dan diterima secara taken for granted dimana wacana laki-laki (being a man) direpresentasikan sebagai imagi maskulin yang memiliki kekuatan fisik, penguasaan ekonomi, rasionalitas, kontrol kekuasaan yang lebih terhadap yang lain, mempunyai hak istimewa, lebih agresif, penentu keputusan, yang bersumber pada kepemilikan status sosio-ekonomi (Connell, 2009).

Representasi maskulin seperti yang diudar di atas tampak nyata dalam berbagai media baik daring, cetak (majalah, koran), iklan, pusat kebugaran, dan berbagai provokasi institusi yang berjeraring dengan kapitalisme (Chapman \& Rutherford, 2014).

Sangat mudah mencari benang merah seperti apa laki-laki yang dilabelkan oleh media-media di atas, seperti apa "laki-laki sejati" dalam iklan rokok, mobil, olahraga, dan segala produk yang menjanjikan imagi "lakilaki impian". Imagi laki-laki yang hegemonik ini secara bersamaan tidak hanya memarjinalkan perempuan, melainkan laki-laki yang "tidak atau kurang ideal", misalnya laki-laki dengan status sosial-ekonomi yang rendah, disabilitas, penuaan dan kerentanan fisik.

Clark et al. (2014) dalam Aging and Masculinity: Potrayal's in Men's Magazines melihat bahwa pentingnya representasi teksual dan visual pada media, karena hal ini akan menuju idealisasi kemana individu mesti terarah dan sebaliknya mempengaruhi bagaimana seseorang memandang usianya.

Selain itu, Feasey (2016) sudah menguji representasi tokoh heroik dalam empat sekuel film Die Hard yang diperankan oleh Bruce Wilis sejak 1988 sampai 2007. Representasi pahlawan tua ini lebih menonjolkan wujud tubuh yang tetap tangguh dan kekuatan yang tidak menyusut dibandingkan dengan kematangan moralitas.

Analisis kritis pada media ini juga menghasilkan temuan bahwa bahwa representasi ini turut melanggengkan dominasi dan hegemoni. Selain itu, penelitian ini menantang irrasionalitas pada imagi pahlawan laki-laki yang terus-menerus mendominasi genre film action yang menampilkan kekuatan otot.

Representasi maskulinitas lakilaki pada film juga dilakukan oleh Saxton \& Cole (2012) terhadap tokoh protagonis pada film No Country for Old Men bertujuan untuk mengungkapkan sisi dinamis maskulinitas hingga masa senja.

Ia menunjukkan bahwa ketika sang tokoh kehilangan sarana untuk menunjukkan maskulinitas tradisional, justru sang tokoh menawarkan hal yang tidak terduga pada pencarian identitas maskulin di akhir usianya. Sang tokoh bergerak meninggalkan identitas maskulinitas tradisional Amerika Barat dalam wujud penanggalan ciri dominasi seorang koboi, yaitu kekerasan. Maskulinitas yang tampak sangat dinamis pada sang tokoh.

Sandberg

(2015)

juga

mengeksplorasi interseksi maskulinitas 
dan penuaan pada ranah seksualitas laki. Studi dengan interpretasi naratif ini mengungkapkan temuan yang kontradiktif. Di satu sisi, hasrat seksual terus menjadi aspek penting pada kehidupan lanjut usia. Pada sisi yang lain, penuaan menjadi masalah gender yang berakibat pada menurunnya hasrat seksual.

Ternyata, Intimasi dapat menjembatani sisi yang saling kontradiktif ini. Melalui narasi tentang keintiman, laki-laki yang tidak ideal dapat mengungkapkan minat seksualitas yang terus berlanjut, namun dengan cara positif dan menghindari stigmatisasi sebagai orang tua yang dianggap jorok. Ambiguitas yang tampak ini dijembatani oleh suatu pencarian nilai melalui intimitas yang melampaui kenikmatan tubuh semata.

Peninjauan ulang terhadap penelitian-penelitian di atas membantu penulis dalam mendapatkan pemetaan konseptual serta mempertimbangkan hambatan dan peluang. Kajian ini, paling tidak memperkaya studi laki-laki dan maskulinitas di Indonesia. Selain itu, Memperluas perspektif interdisipliner antara kajian psikologi yang berinteraksi dengan disiplin lainnya, termsuk sosiologi gender, studi laki-laki dan maskulinitas. Sehingga melahirkan epistemologi yang beragam, termsuk psikologi diskursif.

\section{Maskulinitas dalam Struktur Relasi Gender}

Gender merupakan konstruksi sosial (Connell, 2005; Kimmel, 2011; Ruspini et al., 2011; Pini \& Pease, 2013; Jackson, 2016). Maskulinitas merupakan konfigurasi yang berada di dalamnya dan turut mengonstruksi tatanan gender. Oleh karenanya, menjadi lakilaki atau perempuan bukanlah suatu konsep yang melekat begitu saja. Kelindanan antara self dan social bersama-sama membentuk identitas dan relasi gender.

Term gender berbeda dengan seks (jenis kelamin), yang mana term seks lebih mengacu kepada aparatus biologis, laki-laki dan perempuan yang terbentuk melalui kromosom, kimiawi, dan organisasi anatomis. Sebaliknya, gender mengacu kepada makna yang disematkan atas perbedaan tersebut pada suatu kultur (Kimmel, 2011).

Male dan female merupakan seks atau jenis kelamin, sedangkan masculinity dan femininity merupakan gender, konsep yang menjadikan apaapa dan bagaimana seseorang dianggap dan menjadi man atau women. Sosialisasi perbedaan gender pada suatu kultur sangat menentukan seperti apa konsep maskulin dan feminin pada suatu konteks (Fakih, 2016). Oleh karenanya, sebagai konsep gender, term maskulinitas menjadi kontekstual dan jamak.

Berdasarkan uraian di atas, dapat dipahami bahwa perbedaan gender yang hadir pada tatanan masyarakat merupakan sesuatu yang diciptakan (create). Identitas gender merupakan sesuatu yang terus-menerus dibentuk (becoming). Sebagai contoh, pada masyarakat patriarki-seperti yang dicatat oleh Walby (2014)-peradaban dibentuk oleh laki-laki sehingga perempuan menjadi subordinat. Peminggiran oleh dominasi laki-laki ini beroperasi pada pelbagai ranah dan level: keluarga, sekolah, pergaulan 
sehari-hari, institusi masyarakat, sampai kebijakan negara.

Perbedaan gender terus diciptakan dan diproduksi melalui perbedaan etnis, kelas, usia, seksualitas, disabilitas dan faktor pembeda lainnya yang beroperasi pada media, kepercayaan, budaya, pendidikan, politik, agama, ekonomi yang menghasilkan ketidakadilan gender dalam ruang privat maupun ruang publik. Oleh karenanya, meninjau ulang maskulinitas secara kritis merupakan usaha untuk mempromosikan keadilan gender dan tatanan masyarakat yang lebih manusiawi.

Connell (Whitehead \& Barrett, 2001; Connell, 2005; Widgwood, 2009) memetakan tiga struktur maskulinitas dalam relasi gender, sebagai berikut:

1. Relasi kekuasaan (power relations)

Menurut Connell (2005), sumbu utama kekuasaan pada tatanan gender masyarakat kontemporer dialamatkan pada dominasi dan subordinasi melalui legitimasi patriarki. Penjabarannya, analisis kritis Foucauldian (Foucault, 1978) dapat membantu dalam menjelaskan bahwa relasi kekuasaan tersebar dalam bentuk wacana, tidak selalu dengan jalan kekerasan fisik. Kekuasaan beroperasi melalui strategi-strategi wacana dan pengetahuan.

Haryatmoko (2013; 2016) menyebutkan bahwa kekuasaan sebagai rezim wacana dianggap mampu menggapai, menembus, dan mengontrol individu sampai kepada kenikmatan-kenikmatan yang paling intim. Cara yang dilakukan melalui wacana-wacana yang dirumuskan dalam bentuk

penolakan, pelarangan, perangsangan, rayuan, dan intensifikasi (teknik-teknik kekuasaan yang memiliki banyak bentuk). Sebagai contoh, wacana menjadi cantik, tampan, kekar, macho, merupakan wacana kekuasaan.

2. Relasi produksi (production relations)

Pembagian kerja berdasarkan gender pada institusi keluarga merupakan realitas konkrit bagaimana relasi produksi diterapkan. Ketimpangan tampak pada laki-laki bekerja di luar dan mendapat gaji, sedangkan perempuan bekerja di rumah dan tidak mendapat gaji.

Penguasaan kapital ekonomi berada pada tangan laki-laki. Connell (2005) menyebutnya dengan arena reproduktif. Kondisi ini akhirnya, menjadikan perempuan tidak memiliki sumber daya ekonomi yang mana kontrol ekonomi sepenuhnya dalam penguasaan laki-laki. Penguasaan kapital mencirikan dominasi maskulin melalui arena reproduktif maupun arena produktif.

Bourdieu (2001) menyebut beberapa jenis kapital, diantaranya: kapital ekonomi, kapital kultural, kapital sosial, dan kapital simbolik. Kapital ini dapat saling mengkorversi satu sama lain, tergantung pada arena produksi dan reproduksinya. Dominasi biasanya terjadi pada kelompok yang paling banyak memegang kapital-kapital ini. 
3. Kateksis (chatexis)

Connell (Sedgwood, 2009) meminjam dan mengelaborasi kateksis dari term Freudian, libidinose Besetzung, yaitu hasrat seksual sebagai energi emosional yang melekat pada objek (as emotional energy being attached to an object). Kateksis menjelaskan dan mengatasi antara dualitas tubuh dan sosial.

Connell (2005) lebih lanjut menjelaskan bahwa relasi gender dialami sebagai pengalaman ketubuhan (gairah seksual, ketegangan otot dan postur tubuh, kenyamanan dan ketidaknyamanan) dan sekaligus terbentuk oleh dalam tindakan ketubuhan (olahraga, seksualitas, bekerja). Singkatnya, kelekatan emosional pada apa yang membentuk hasrat dan realisasi hasrat secara timbal-balik merupakan aspek yang membentuk tatanan gender.

Ketiga struktur maskulinitas ini dalam strukturasi praktik sosial bukanlah tipe khusus dari suatu praktik secara umum, melainkan keterlibatannya dengan struktur sosial lainnya. Pada titik ini, interseksi gender akan mempunyai implikasi yang penting dalam analisis maskulinitas (Connell, 2005).

Pada alasan inilah interseksi maskulinitas dan posisi laki-laki nonhegemonik mendapat legitimasi ilmiahnya. Berbekal pemetaan konseptual struktur maskulinitas di atas, dinamika maskulinitas pada lakilaki perlu dielaborasi dari tiga struktur di atas, yaitu: relasi kekuasaan untuk melihat posisi laki-laki lansia dalam kontestasi struktur gender, relasi produksi untuk melihat independensi sumber daya, relasi emosional untuk menggeledah hasrat dan keterlibatan dengan dirinya sendiri dan sosial.

\section{Kesimpulan}

Wacana maskulinitas dalam suatu kultur patriaki merupakan wacana dominasi. Connell (2005) mengucapkannya dengan hegemonic masculinity. Konsep sentral ini berguna sebagai 'seperangkat teropong' untuk mendeteksi relasi yang instrumentalistik baik hubungan antara perempuan dan laki-laki, maupun lakilaki dengan laki-laki.

Teropong hegemonic masculinity juga berguna untuk melihat pola relasi antara konstruksi sosial dominansubordinat. Dengan demikian, cederanya keadilan dan kesetaraan dapat diteropong dari pembongkaran relasi-relasi seperti yang diuraikan di atas.

\section{Daftar Pustaka}

Aboim, S. (2010). Plural Masculinities: The Remaking of the Self in Private Life. Farnham: Ashgate

Akman, C. A. (2013). Islamic Women's Ordeal with the New Face(s) of Patriarchy in Power: Divergence or Convergence Over Expanding Women's Citizenship? In Donmez, R. O. \& Ozmen, F. A (eds.), Gendered identities: Criticizing patriarchy in Turkey. United Kingdom: Lexington Books.

Asadi, M. (2010). Militarization and Gender: Pathways to a ViolenceBased Patriarchy. Journal for the 
Study of Peace and Conflict, 1: 100121.

Barker, G. T. (2005). Dying To Be Man: Youth, Masculinity, and Social Exclusion. London: Routledge.

Bourdieu, P. (2001). Masculine Domination. Terjemahan: Nice, $\mathrm{R}$. Stanford: Stanford University Press. Buchbinder, D. (2013). Studying Men and Masculinities. London: Routledge.

Chapman, R., \& Rutherford, J. (ed.). (2014). Male Order: Menguak Maskulinitas. Penerjemah: Fitria Mayasari. Yogyakarta: Jalasutra.

Clark, L. H., Bennett, E. V., \& Liu. C. (2014). Aging and Masculinity: Potrayal's in Men's Magazines. Journal of Aging Studies, 31: 26-33.

Connell, R. (2005). Masculinities. $2^{\text {nd }}$ Edition. Cambridge: Polity.

Connell, R. (2009). Gender in World Perspective. $2^{\text {nd }}$ Edition. Cambridge: Polity.

Connell, R., \& Messerschmidt, J. W. (2005). Hegemonic Masculinity: Rethinking the Concept. Gender $\mathcal{E}$ Society, 19(6): 829-859.

Courtenay, W. H. (2000). Constructions of Masculinity and Their Influence on Men's Well-Being: A Theory of Gender and Health. Social Science $\mathcal{E}$ Medicine, 50(10): 1385-1401.

Davis, I. (2015). Stories of Men and Teaching: A New Narrative Approach to Understanding Masculinity and Education. London: Springer.

Evans, J., Frank, B., Oliffe, J. L., \& Gregory, D. (2011). Health, Illness, Men and Masculinities (HIMM): a Theoretical Framework for Understanding Men and Their Health. Journal of Men's Health, 8(1): 7-15.
Fakih, M. (2016). Analisis Gender dan Transformasi Sosial, edisi terbarukan. Yogyakarta: Insist.

Feasey, R. (2008). Masculinity and Popular Television. Edinburgh: Edinburgh University Press.

Feasey, R. (2011). Mature Masculinity and the Ageing Action Hero. Groniek, 190: 507-519.

Flood, M. (2002). Between Men and Masculinties: An Assessment of the Term "Masculinity" in Recent Scholarship on Men, in Pearce, S. \& Muller, V. (eds). Manning the Next Millennium: Studies in Masculinities. Bentley: Black Swan Press.

(2010). Young Men Using Pornography, in Boyle, K. (ed). Everyday Pornography. London: Routledge.

. (2016). Inquiry into the Harm Being Done to Australian Children through Access to Pornography on the Internet. Submission, Senate March 10.

Flood, M., Gardiner, J.K., Pease, B., \& Pringle, K. (eds). (2007). International Encyclopedia of Men and Masculinities. London: Routledge.

Foucault, M. (1987). The History of Sexuality. Volume I: An Introduction. Terjemahan: Hurley, R. New York: Pantheon Book.

Fulu, E., Warner, X., Miedema, S., Jewkes, R., Roselli, T., \& lang. J. (2013). Why Do Some Men Use Violence against Women and How Can We Prevent It? Quantitative Findings from the United Nation Multi-Country Study on Men and Violence in Asia and the Pacific. Bangkok: Partners for Prevention. 
A UNDP, UNFPA, UN Women and UNV Regional Joint Programme for Gender-Based Violence Prevention in Asia and the Pacific.

Greig, A., Kimmel, M., \& Lang, J. (2000). Men, Masculinities, and Development: Broadening Our Work toward Gender Equality. UNDP Report.

Haryatmoko. (2013). Sejarah

Seksualitas: Sejarah Pewacanaan

Seks dan Kekuasaan menurut Foucault. In Handayani, C.S., dkk. Subjek yang Dikekang: Pengantar ke Pemikiran Julia Kristeva, Simone de Beauvoir, Michel Foucault, Jacques Lacan. Jakarta: Komunitas Salihara-Hivos.

(2016). Membongkar Rezim Kepastian: Pemikiran Kritis PostStrukturalis. Yogyakarta: Kanisius. Hasyim, N., Kurniawan, A. P., \& Hayati, E. N. (2011). Menjadi Laki-Laki: Pandangan Laki-Laki Jawa tentang Maskulinitas dan Kekerasan dalam Rumah Tangga (Being a Man: Javanese Male Perspectives about Masculinity and Domestic Violence). Yogyakarta: Rifka Annisa.

Hayati, E.N., Emmelin, M., \& Eriksson, M. (2014). "We no longer live in the old days": a Qualitative Study on the Role of Masculinity and Religion for Men's Views on Violence within Marriage in Rural Java, Indonesia. BMC Women's Health, 14(58); 1-13.

Howson, R. (2006). Challenging Hegemonic Masculinity. London: Routledge.

Ismail, S. F. S. (2014). In Pursuit of Mr. Right: Constructed Masculinities in Malay Teen Magazine. ProcediaSocial and Behavioral Sciences, 155: 477-483.

Jackson, D. (2016). Exploring Aging Masculinities: The Body, Sexuality, and Social Lives. London: Palgrave Macmillan.

Kimmel, M. \& Messner, M. (2007). "Introduction" in Men's Lives. $7^{\text {th }}$ edition. Boston: Allyn and Bacon.

Kimmel, M. (2008). The Gendered Society. $3^{\text {rd }}$ Edition. Oxford: Oxford University Press.

Lesko, N. (ed.). (2000). Masculinities at School. Thousand Oaks, CA: Sage.

Lingard, B., Martino, W., \& Mills, M. (2009). Educating Boys: Beyond Structural Reform. London: Palgrave.

Lohan, M. (2007). How Might We Understand Men's Health Better? Integrating Explanations from Critical Studies on Men and Inequalities in Health. Social Science \& Medicine, 65: 493-504.

Nilan, P. (2009). Contemporary Masculinities and Young Men in Indonesia. Indonesia and Malay World, 37(109): 327-344.

Permanadeli, R. (2015). Dadi Wong Wadon: Representasi Sosial Perempuan Jawa di Era Modern. Yogyakarta: Pustaka Ifada.

Pini, B. \& Pease, B. (eds). (2013). Men, Masculinities and Methodologies. New York: Palgrave MacMillan.

Robertson, S., William, B., \& Oliffe, J. (2016). The Case for Retaining a Focus on "Masculinities" in Men's Health Research. International Journal of Men's Health, (15)1: 52-67. Ruspini, E., Hearn, J., Pease, B., \& Pringle, K. (2011). Men and 


\section{Masculinities around the World:}

Transforming Men's Practices. New York: Palgrave MacMillan.

Sandberg, L. (2015). In Lust We Trust? Masculinity and Sexual Desire in Later Life, Men and Masculinities, 19(2): 192-208.

Saxton, B. \& Cole, T. R. (2012). No Country for Old Men: A Search for Masculinity in Later Life. International Journal of Ageing and Later Life, 7(2): 97-116.

Smith, A. (2007). Beyond Masculine Stereotypes: Moving Men's Health Promoting Forward in Australia. Health Promotion Journal of Australia, 18(1): 20-25.

UNDP, USAID, BPS, Rifka Annisa. (2016). Study on Women's and Men's Health and Life Experiences in Papua, Indonesia. UNDP Report. Walby, S. (2014). Teorisasi Patriarki. Terjemahan: Prasela, M.K. Yogyakarta: Jalasutra.

Whitehead, S. M. \& Barrett, F. J. (eds). (2001). The Masculinities Reader. Cambridge: Polity.

Wong, Y. J., Ho, M. R., Wang, S., \& Miller, I. S. K. (2016). Journal of Counseling Psychology, Advance Online Publication. http://dx.doi.org/10.1037/ cou0000176. 